\title{
T-Cell Surface Glycoprotein CD8 Beta
} Chain

National Cancer Institute

\section{Source}

National Cancer Institute. T-Cell Surface Glycoprotein CD8 Beta Chain. NCI Thesaurus. Code C17441.

T-cell surface glycoprotein CD8 beta chain (210 aa, $~ 24 \mathrm{kDa}$ ) is encoded by the human CD8B gene. This protein plays a role in T-cell cytotoxicity. 